\title{
ГЕОХИМИЧЕСКИЙ ТИП НЕОАРХЕЙСКИХ СУБЩЕЛОЧНЫХ ПОРОД КЕЙВСКОЙ СТРУКТУРЫ
}

\section{Ветрин B.P.}

Геологический институт КНЦ РАН, Апатиты, ИМГРЭ, Москва, vetrin@geoksc.apatity.ru

Самые древние в истории Земли щелочные и субщелочные породы калиевой специфики известны в кратоне Пилбара Западной Австралии [11], тогда как первые геологически значимые проявления щелочного магматизма во многих кратонах Земли приурочены к интервалу времени 2.5-2.7 млрд. лет $[8,13,14,4,1]$. Одним из таких регионов является Кольский полуостров, в центральной части которого расположена неоархейская щелочная провинция, занимающая площадь

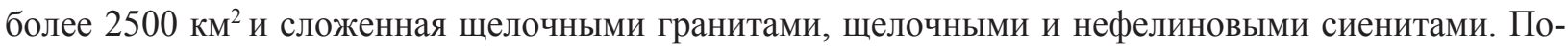
мимо щелочных пород в состав провинции входят породы субщелочного состава, по времени образования более ранние по отношению к щелочным гранитам, и выделенные в составе неоархейской вулкано-плутонической ассоциации латитов- монцонитов- гранитов [2].

Образование исходных магм ассоциации предполагается за счет плавления метасоматически измененных пород основного состава при внедрении в нижнюю кору базитовых расплавов, исходных для пород дайкового комплекса и массивов габбролабрадоритов (см. статью B.P. Ветрина в
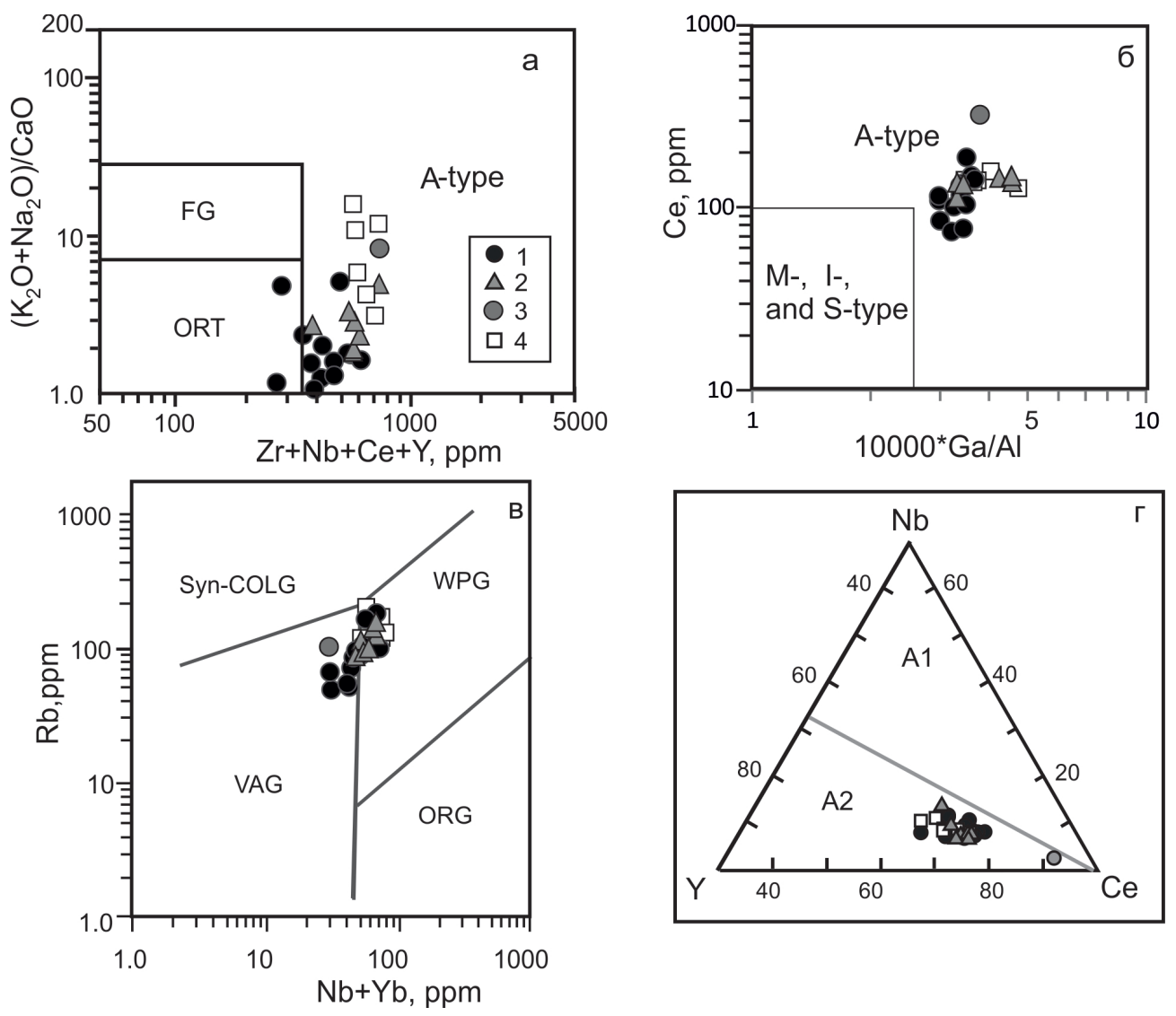

Рис. 1. Диаграммы тектонической дискриминации гранитоидов: $\mathrm{Zr}+\mathrm{Nb}+\mathrm{Ce}+\mathrm{Y}-\mathrm{FeOt} / \mathrm{MgO}$ (а) и $100000 * \mathrm{Ga} / \mathrm{Al}$ (б) [15], Y+Nb - Rb (в) [12], Y- Nb- Се (г) [6]. FG- фракционированные лейкократовые граниты, OGT- поле составов M-, I-, S-типов гранитоидов, VAG- граниты островных дуг, sin-COLG- синколлизионные граниты, ORG- граниты океанических хребтов, WPG- внутриплитные граниты. A1- гранитоиды A-типа анорогенных обстановок, А2- постколлизионные, посторогенные и анорогенные гранитоиды А-типа, формировавшиеся из базальтового источника островных дуг и континентальных окраин, или за счет переработки континентальной коры. 1 - метаэффузивы, 2 - породы гипабиссальной фации, 3 - жильный лейкогранит, 4 - порфировидные граниты мезоабиссальной фации глубинности. 


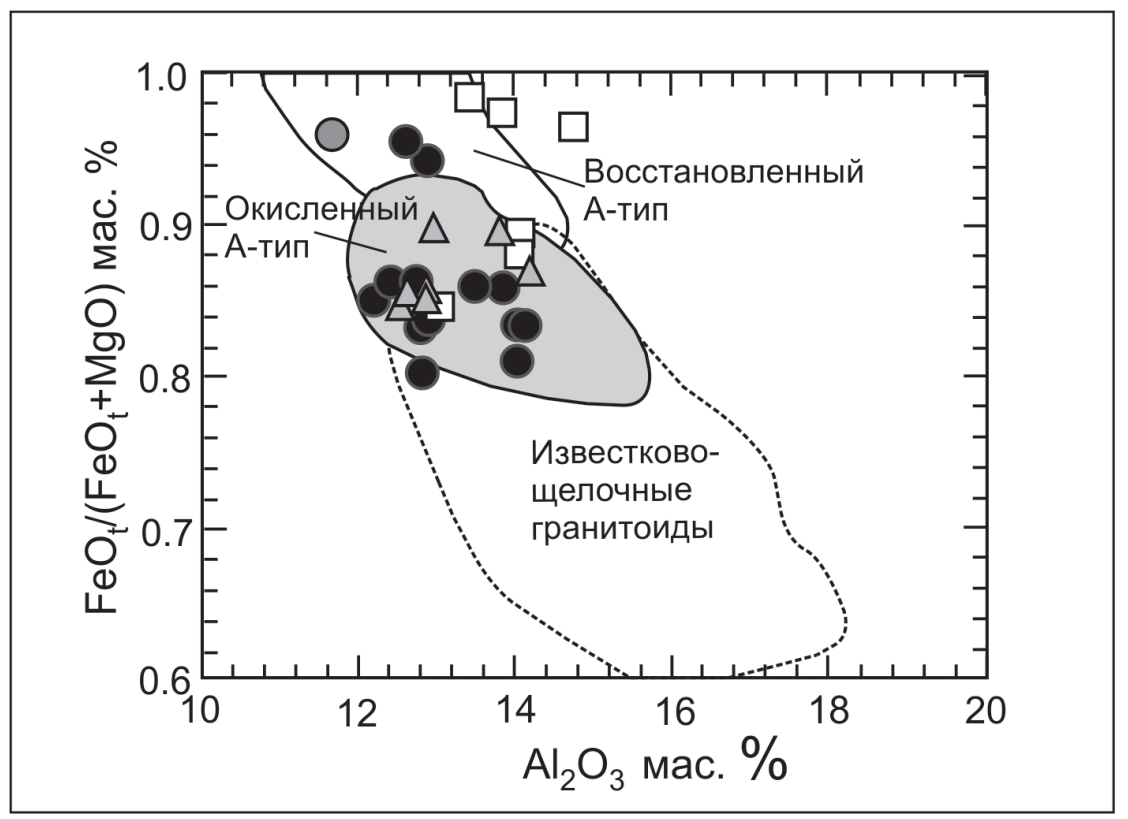

Рис. 2. Диаграмма классификации гранитоидов А-типа в координатах $\mathrm{Al}_{2} \mathrm{O}_{3}-\mathrm{FeOt} /(\mathrm{FeOt}+\mathrm{MgO})$, по [5]. Условные обозначения см. рис. 1.

настоящем сборнике). Температура расплава метаэффузивов, определенная по фосфорному и титановому геотермометрам, составляет $970^{\circ} \mathrm{C}$ и $960^{\circ} \mathrm{C}$. Для кварцевых монцонитов гипабиссальной фации средние значения температур определены, соответственно, в $970^{\circ} \mathrm{C}$ и $940^{\circ} \mathrm{C}$, и для порфировидных гранитов- в $930^{\circ} \mathrm{C}$ и $<900^{\circ} \mathrm{C}$. Приведенные цифры характеризуют высокотемпературный характер исходных расплавов метаэффузивов и гранитоидов, что свойственно производным недосыщенным водой расплавов. Определение давления в процессе формировании расплавов выполнено по нормативной диаграмме в координатах кварц- ортоклаз- альбит. Средние составы пород ассоциации расположены в районе «гранитного минимума» при $\mathrm{a}_{\text {н2о }}=0.5$ и давлении $\sim 5-6$ кбар, и приведенные значения давления определяют глубину образования расплавов в 20-25 км. Поскольку гранитные магмы при давлении 5 кбар могут растворять до 10\% воды, ее количество в расплавах, исходных для пород ассоциации, ориентировочно может быть оценено как $\leq 5 \%$. Внутриочаговая кристаллизация преимущественно безводных минеральных ассоциаций рестита приводила к увеличению содержания воды в расплаве, и, соответственно, к уменьшению амплитуды перемещения расплавов к поверхности, максимальной для метаэффузивов, и минимальной для порфировидных гранитов. Давление воды при кристаллизации пород гранофировой и микропегматитовой структур в метаэффузивах и кварцевых монцонитах определено в $\sim 0.5$ кбар при температуре $730-820^{\circ} \mathrm{C}$. Температура образования «отожженного» амфибол-плагиоклазового парагенезиса в порфировидных гранитах при давлении воды около 5 кбар не превышала $425^{\circ} \mathrm{C}$.

Породы ассоциации имеют пониженную величину отношения $\mathrm{Al} /(\mathrm{Na}+\mathrm{K})$, высокую железистость, повышенные концентрации крупноионных, высокозарядных и редкоземельных элементов, и по этим критериям отвечают гранитам А-типа [10]. На диаграммах Дж. Велина [15] рассматриваемые породы локализованы в поле гранитов А-типа (рис. 1, a, б), и в координатах $(\mathrm{Nb}+\mathrm{Yb})-\mathrm{Rb}$ [12] преобладающее количество точек состава соответствует внутриплитным гранитам (рис. 1, в). На тройной Y-Nb-Се диаграмме метавулканиты и гранитоиды локализованы в поле $\mathrm{A}_{2}$, (рис. 1, г), отвечающему составам постколлизионных, посторогенных и анорогенных гранитов, формировавшихся из базальтового источника островных дуг и континентальных окраин, или за счет переработки континентальной коры [6].

В отличие от наиболее распространенных гранитов А-типа, кристаллизовавшихся в восстановительных условиях $[10,7]$ и относящихся к ильменитовой серии [9], метавулканиты и гипабиссальные гранитоиды ассоциации содержат повышенное количество магнетита (до 4 \%) при его существенном преобладании над ильменитом, что определяет отнесение этих пород к производным маг- 
нетитовой серии. Для подобных гранитоидов введен термин «окисленный $A$-тип» [3]. По концентрациям $\mathrm{Al}_{2} \mathrm{O}_{3}$ и величине отношения $\mathrm{FeO} /(\mathrm{FeO}+\mathrm{MgO})$ граниты окисленного А-типа занимают промежуточное положение между полями составов известково-щелочных гранитов и восстановленных гранитов А-типа (рис. 2). На рассматриваемой диаграмме преобладающая часть точек метаэффузивов и кварцевых монцонитов располагается в поле окисленных А- гранитов, тогда как часть порфировидных гранитов тяготеет к полю восстановленных А-гранитов. Кристаллизация окисленных A- гранитов предполагается из магм, образованных при плавлении пород нижней коры в условиях повышенной активности кислорода [5].

Оценка активности кислорода при кристаллизации изученных пород выполнена по методу Д. Уонса [16]. Полученные данные показывают существенное уменьшение $\mathrm{fO}_{2}$ от метаэффузивов $\left(\log \mathrm{fO}_{2}=-13--15\right)$ и кварцевых монцонитов $\left(\log \mathrm{fO}_{2}=-16\right)$ к порфировидным гранитам $\left(\log \mathrm{fO}_{2}=-28\right)$. Пониженной активностью кислорода, обусловленной, вероятно, относительно низкотемпературными условиями кристаллизации порфировидных гранитов, определялось нахождение железа в двухвалентной форме, его растворение в силикатных фазах - биотите и амфиболе, и незначительное количество магнетита $(\leq 5$ г/т) в породе.

Увеличением $\mathrm{fO}_{2}$ при кристаллизации эффузивов и гранитоидов гипабиссальной фации была обусловлена повышенная магнезиальность биотита и амфибола, высвобождение из их структуры железа и кристаллизация магнетита, концентрация которого в породах достигает, соответственно, $4 \%$ и $0.6 \%$. Приведенные данные показывают существенное влияние интенсивных параметров $\left(\mathrm{P}, \mathrm{T}, \mathrm{fO}_{2}\right)$ на формирование магнетитового и безмагнетитового парагенезисов в породах.

Гранитоиды окисленного $A$-типа наиболее полно изучены в кратонах Амазония и Лаврентия Южной и Северной Америки ([5] и ссылки в статье). На Балтийского щите к окисленному $A$-типу относятся порфировидные гранитоиды ряда массивов в северо-западной части Кольской провинции и на территории Финляндии.

Исследования выполнены при поддержке РФФИ (гранты 17-35-50002, 16-05-00026а), и госконтракта № 13/17-1.

\section{Литература}

1. Балашов Ю.А., Глазнев В.Н. Циклы щелочного магматизма // Геохимия. 2006. №3. С. 309-321.

2. Ветрин В.Р., Родионов Н.В. Геология и геохронология неоархейского анорогенного магматизма Кейвской структуры, Кольский полуостров // Петрология. 2009. Т. 17. № 6. С. 578-600.

3. Anderson J.L., Bender E.E. Nature and origin Proterozoic A-type granitic magmatism in the southwestern United States of America // Lithos. 1989. V. 23. P. 19-52.

4. Blichert-Toft J., Arndt N.T., Ludden J.N. Precambrian alkaline magmatism // Lithos. 1996. V. 37. P. 97-111.

5. Dall'Agnol R., Oliveira D. C. Oxidized, magnetite- series, rapakivi-type granites of Carajás, Brazil: Implications for classification and petrogenesis of A-type granites // Lithos. 2007. V. 93. P. 215-233.

6. Eby G.N. Chemical subdivision of the A- type granitoids: petrogenetic and tectonic implication // Geology. 1992. V. 20. P. 641-644.

7. Frost C.D., Frost B.R. Reduced rapakivi type granites: the tholeiitic connection // Geology. 1997. V. 25. P. 647-650.

8. Hill R.I., Chappell B.W., Campbell I.H. Late Archaean granites of the southeastern Yilgarn Block, Western Australia: age, geochemistry, and origin. Trans. Royal Soc. Edinburgh Earth Sci. 1992. V. 83. P. 211-226.

9. Ishihara S., The granitoid series and mineralization // Economic Geology 75th Anniversary volume. 1981. P. 458-484.

10. Loiselle M. C., Wones D.R. Characteristics and origin of anorogenic granites // Geol. Soc. of America, Abstracts with Programs. 1979. V. 11 (3). P. 468.

11. Nelson D.R., Trendall A.F., Altermann W. Chronological correlations between the Pilbara and Kaapvaal cratons // Precambr. Research. 1999. V. 97. P. 165-189.

12. Pearce J.A., Harris N.B.W., Tindle A.G. Trace element discrimination diagrams for the tectonic interpretation of granitic rocks // Journ. Petrol. 1984. V. 25. P. 956-983.

13. Stuckless J.S., Miesch A.T., Wenner D.B. Geochemistry and petrogenesis of an Archean Granite from the Owl Creek Mountains, Wyoming. // USGS Prof. Paper 1388-A. 1986. P. 1-21.

14. Taylor P.N., Chadwick B.,Moorbath S., Ramakrishnan M., Viswanatha M.N. Petrography, chemistry and isotope ages of Peninsular gneiss, Dharwar acid volcanic rocks and the Chitradurga granite with special reference to the late Archaean evolution of the Karnataka craton, Southern India // Precambr. Research. 1984. V. 23. P. 349-375.

15. Whalen J.B., Currie K.L., Chappell B.W. A- type granite: geochemical characteristics, discrimination and petrogenesis // Contrib. Mineral., Petrol. 1987. V. 95. P. 407-419.

16. Wones D. R. Significance of the assemblage titanite+ magnetite +quartz in granitic rocks // Amer. Mineral. 1989.V. 74. P. 744-749. 